\title{
Delivery and birth indicators of seropositive women for the human immunodeficiency virus
}

\author{
Indicadores de parto e nascimento de mulheres soropositivas para vírus da \\ imunodeficiência humana
}

Régia Christina Moura Barbosa Castro ${ }^{1}$, Silvia Maria Gomes ${ }^{1}$, Ana Kelve de Castro Damasceno ${ }^{1}$, Clara Viviane Gomes Bastos ${ }^{2}$, Lorena Carlos Araújo ${ }^{1}$, Tatiane da Silva Coelho ${ }^{3}$

\begin{abstract}
Objective: to evaluate delivery and birth indicators of seropositive parturient women for the human immunodeficiency virus. Methods: this is a documentary study held with 92 medical records of seropositive women for the human immunodeficiency virus, with analysis of sociodemographic, obstetric and neonatal variables. The chi-square test was used to verify association between predictor variables and outcome. Results: parturient women received prophylaxis perinatal (77.2\%) and delivery (91.3\%); 52.2\% of them performed seven prenatal consultations. $8.7 \%$ of newborns were preterm, $18.5 \%$ were underweight, and $92.4 \%$ received antiretroviral prophylaxis in the first 24 hours of birth. Conclusion: Vulnerability and the highest risk of illness occur in young adults with low education and socioeconomic status. The coverage indicator of pregnant women needs to improve their indexes, since a little more than half of the women performed seven antenatal consultations, negatively impacting the evolution of pregnancy with a percentage of pregnancy prophylaxis below the desired.
\end{abstract}

Descriptors: Pregnancy, High-Risk; HIV; Pregnant Women; Indicators (Statistics); Health Status.

Objetivo: avaliar os indicadores de parto e nascimento das parturientes soropositivas para vírus da imunodeficiência humana. Métodos: estudo documental realizado com 92 prontuários e fichas de investigação de mulheres soropositivas para vírus da imunodeficiência humana, com análise das variáveis sociodemográficas, obstétricas e neonatais. Utilizou-se o teste qui-quadrado para verificar associação entre as variáveis preditoras e desfecho. Resultados: as parturientes receberam profilaxias perinatais $(77,2 \%)$ e no parto $(91,3 \%) ; 52,2 \%$ realizaram sete consultas pré-natais. Quanto aos recém-nascidos, 8,7\% nasceram prematuros, 18,5\% com baixo peso e 92,4\% receberam profilaxia com antirretroviral nas primeiras $24 \mathrm{~h}$ do nascimento. Conclusão: a vulnerabilidade e o maior risco de adoecer ocorrem em adultos jovens, com escolaridade e nível socioeconômico baixos. 0 indicador de cobertura de gestantes necessita melhorar seus índices, uma vez que pouco mais da metade das mulheres realizou sete consultas pré-natais, impactando negativamente na evolução da gravidez com percentual de profilaxias na gestação abaixo do desejado.

Descritores: Gravidez de Alto Risco; HIV; Gestantes; Indicadores (Estatística); Nível de Saúde.

\footnotetext{
${ }^{1}$ Universidade Federal do Ceará. Fortaleza, CE, Brazil.

${ }^{2}$ Universidade Federal Fluminense. Niterói, RJ, Brazil.

${ }^{3}$ Maternidade Escola Assis Chateaubriand. Fortaleza, CE, Brazil.

Corresponding author: Tatiane da Silva Coelho

Rua Professor Manoel Lourenço, 95 Jóquei Clube - CEP: 60510-107. Fortaleza, CE, Brazil. E-mail: tatiane25coelho@gmail.com
} 


\section{Introduction}

Acquired Immunodeficiency Syndrome is among the world's health priorities since, despite the annual reduction in disease-related deaths and significant progress in preventing new human immunodeficiency virus (HIV) infections, the number of people living with HIV is still growing ${ }^{(1)}$.

By the end of 2016, there were approximately 36.7 million HIV-infected people in the world and the estimate for 2018 is 1.8 million new people infected, with $54 \%$ of HIV infection in adults and $43 \%$ in children are receiving antiretroviral treatment ${ }^{(2)}$.

According to the epidemiological bulletin HIV/ Acquired Immunodeficiency Syndrome (HIV/AIDS), there were 194,217 cases of HIV infection reported in Brazil in 2017. Of them, 96,439 were in the Southeast, 40,275 in the South, 30,297 in the Northeast, 12,931 in the Midwest and 14,555 in the North of the country. In 2016, there were 136,945 cases reported, 71,396 in the Southeast, 28,879 in the South, 18,840 in the Northeast, 9,152 in the Midwest and 6,868 in the North, which corresponds to an increase of more than 57,000 reported $\operatorname{cases}^{(3)}$.

The high number of women in a reproductive age infected by the virus is one of the aspects related to the process of feminization of $\mathrm{HIV}^{(4)}$, in which vertical transmission is the main route of virus infection in the child population, with $90.0 \%$ of cases in children under 13 years old in Brazil ${ }^{(1)}$. In the last ten years, Brazil had approximately 99,804 pregnant women infected with HIV, where there is a trend of growth in all regions in numerical terms, except in the Southeast region, which remained stable, with the North and Northeast regions showing the greatest rate increases. However, this exception has not been investigated and not clarified as to its association with policies or $\operatorname{programs}^{(3)}$.

The reduction of HIV morbidity and mortality is mainly due to the implementation of antiretroviral therapy (ART), initiated in Brazil in 1996, resulting in an increase in patient survival, through reconstitution of immune system functions and reduction of secondary diseases ${ }^{(1)}$.

Since antiretroviral therapy has increased the survival of people living with HIV/AIDS and the complementarity of policies aimed at the female patients, including pregnant women, it is essential that the health professional is adequately qualified to act correctly and professionally in the care of the mother with HIV, as well as to carry out the interventions in the treatment of the vertical transmission, applying the appropriate actions recommended by the Ministry of Health, guaranteeing a decent and quality assistance for the pregnant woman.

Therefore, with Nursing as a science based on the process of humanization and with the aim of contributing to a differential care of the pregnant women living with HIV/AIDS, this study proposed evaluating the indicators of delivery and birth in HIV-positive women.

\section{Methods}

This is a documentary study, developed in the delivery room of a maternity school in Fortaleza, Ceará, Brazil, which provides care to HIV positive parturient women. This maternity has outpatient service, hospitalization in infirmaries, intensive care unit, laboratory and imaging exams, in addition to prenatal care for these women. The data were collected from September 2015 to August 2016. To meet the objectives of this research, the sample consisted of the entire population, making a total of 92 medical records.

The records of the investigation of pregnant women with HIV, from the Information System of Notifiable Diseases, were used, which are included in the maternity ward attendant's file, belonging to the archive of the Epidemiological Surveillance Nucleus.

The variables evaluated were: maternal age, 
education level, origin, personal income, obstetric profile/parity, gestational age, prenatal consultation, number of consultations, delivery method, perinatal prophylaxis, prophylaxis during delivery, Apgar at the $1^{\text {st }}$ and $5^{\text {th }}$ minute, prematurity, low birth weight, and onset of antiretroviral prophylaxis in the child.

The data obtained were organized in Microsoft Excel 2007 and processed in the Stack Package Software for the Social Sciences version 22. For descriptive statistics, the absolute and relative frequency were used., the Pearson chi-square test was used to compare proportions between two qualitative variables and to verify the association between the predictor variables and outcome, establishing the level of significance in $0.05(5 \%)$, considering statistically significant a value of $\mathrm{p}<0.05 \%$.

Research approved by the Research Ethics Committee of the Federal University of Ceará, under opinion 1,684,572.

\section{Results}

Regarding the characterization of seropositive women in the sociodemographic data, a predominance of women over 18 years old, brown race, with incomplete primary education, from the interior and without personal income was observed as shown in Table 1.

Table 1 shows the distribution of prenatal and delivery variables. It was found that $95.7 \%$ of the women underwent prenatal care, with more than seven visits (52.2\%), half had their deliveries through elective cesarean section $(50.0 \%)$, had perinatal prophylaxis (77.2\%), at the time of delivery (91.3\%), and their newborns were born alive (93.5\%).

Table 2 analyzed the variables related to the newborn. It was observed that the results showed term newborns, suitable for gestational age and that started prophylaxis with the antiretroviral in the first 24 hours.
Table 1 - Distribution of sociodemographic and obstetric data of seropositive parturient women in a maternity school Education level

\begin{tabular}{|c|c|}
\hline Variables & $\mathbf{n}(\%)$ \\
\hline \multicolumn{2}{|l|}{ Age } \\
\hline $12-18$ & $3(3.3)$ \\
\hline$>18$ & $89(96.7)$ \\
\hline \multicolumn{2}{|l|}{ Education level } \\
\hline Elementary school & $51(55.4)$ \\
\hline High school & $37(40.3)$ \\
\hline Higher education & $4(04.3)$ \\
\hline \multicolumn{2}{|l|}{ Prenatal } \\
\hline Yes & 88 (95.7) \\
\hline No & $4(04.3)$ \\
\hline \multicolumn{2}{|l|}{ Number of consultations } \\
\hline$<7$ & $44(47.8)$ \\
\hline$\geq 7$ & $48(52.2)$ \\
\hline \multicolumn{2}{|l|}{ Delivery method } \\
\hline Vaginal & $12(13.0)$ \\
\hline Elective cesarean section & $46(50.0)$ \\
\hline Emergency Caesarean section & $29(31.5)$ \\
\hline Not applicable (miscarriage) & $5(05.5)$ \\
\hline \multicolumn{2}{|l|}{ Perinatal prophylaxis } \\
\hline Yes & $71(77.2)$ \\
\hline No & $21(22.8)$ \\
\hline \multicolumn{2}{|l|}{ Delivery prophylaxis } \\
\hline Yes & $84(91.3)$ \\
\hline No & $8(08.7)$ \\
\hline \multicolumn{2}{|l|}{ Evolution of pregnancy } \\
\hline Born alive & $86(93.5)$ \\
\hline Stillborn & $1(01.1)$ \\
\hline Miscarriage & $5(05.4)$ \\
\hline
\end{tabular}


Table 2 - Distribution of data on birth conditions and prophylaxis of newborns of HIV-positive women in a maternity school

\begin{tabular}{lc}
\hline Variables & n (\%) \\
\hline Prematurity & \\
Yes & $8(8.7)$ \\
No & $84(91.3)$ \\
Low weight & \\
Yes & $17(18.5)$ \\
No & $75(81.5)$ \\
Onset of antiretroviral therapy in children & \\
In the first 24 hours & $85(92.4)$ \\
Not applicable & $6(6.5)$ \\
Ignored & $1(1.1)$ \\
\hline
\end{tabular}

Table 3 shows the statistical association between the number of prenatal consultations of HIV-seropositive women and the prematurity of exposed children, with an association between the number of consultations with prematurity $(\mathrm{p}=0.019)$.

Pearson's Chi-square test was used to compare proportions between two qualitative variables and to verify the association between predictor variables and outcome considering a $5 \%$ level of significance. Also, Pearson's Chi-square test is the most suitable statistical test to be used in studies with a larger samples $(n>40)$.

Table 3 - Association between number of prenatal consultations and origin, mother's age, prematurity and low birth weight of newborns exposed to HIV virus in a maternity school

\begin{tabular}{|c|c|c|c|}
\hline \multirow{2}{*}{ Variables } & \multicolumn{2}{|c|}{ Number of consultations } & \multirow{2}{*}{$\mathbf{p}^{*}$} \\
\hline & $>7 \mathrm{n}(\%)$ & $\leq 7 \mathrm{n}(\%)$ & \\
\hline \multicolumn{4}{|l|}{ Origin } \\
\hline Interior & $23(45.1)$ & $28(54.9)$ & 0.559 \\
\hline Capital & $21(51.2 \%)$ & $20(48.8 \%)$ & \\
\hline \multicolumn{4}{|c|}{ Age (years old) } \\
\hline $12-18$ & $2(66.7)$ & $1(33.3)$ & 0.507 \\
\hline$>18$ & $42(47.2)$ & $47(52.8)$ & \\
\hline \multicolumn{4}{|c|}{ Prematurity } \\
\hline Yes & 7 (15.9) & $1(2.1)$ & 0.019 \\
\hline No & $37(84.1)$ & 47 (97.9) & \\
\hline \multicolumn{4}{|c|}{ Low weight } \\
\hline Yes & $10(22.7)$ & $7(14.6)$ & 0.315 \\
\hline No & $34(77.3)$ & $41(85.4)$ & \\
\hline
\end{tabular}

\section{Discussion}

As a limitation, there is a lack of data available by the institution, regarding the real numbers on incidence, prevalence of seropositive women and their newborns, and studies are needed to show this reality transversally. However, it is considered important to maintain serological screening in pregnant women to establish early diagnosis and treatment and/or preventive measures to avoid mother-to-child transmission of these infections, confirming the importance of determining the vital risks related to the conditions of the treatment birth process.

In the context of HIV/AIDS in the female population, the health professionals need to be prepared to consider the biological, psychological and social dimension of women in the pregnancy-puerperal cycle. Knowing the sociodemographic profile and health indicators of this population refers to specialized care, focused on the integrality of being a woman with HIV/ $\operatorname{AIDS}^{(5-6)}$.

In the analysis of the sociodemographic profile, it was verified that the age group was concentrated in women older than 18 years old, showing a relevant dynamics in other studies ${ }^{(4-7)}$, revealing that they are young, sexually active and reproductive-aged women.

Most women had incomplete elementary school. Education level is a variable that has been used a marker of the socioeconomic conditions of HIV patients, according to the current epidemiological pattern of the epidemic. Studies have shown that, over the years, there has been an increase in the number of cases among patients with lower levels of education and less skilled occupations. This decrease in the level of education of pregnant women with HIV has been widely cited as an indicator of pauperization of the epidemic $^{(7)}$.

Regarding the stages of prevention of vertical transmission, the first stage is the early diagnosis of HIV infection in pregnant women. Prenatal care may contribute to more favorable outcomes by allowing the detection and timely treatment of conditions, as 
well as controlling risk factors that bring complications to the health of women and the baby ${ }^{(8)}$.

The new Clinical Protocol and Therapeutic Guidelines for Prevention of Vertical Transmission of HIV, Syphilis and Viral Hepatitis advocate antiretroviral therapy for all HIV-infected pregnant women regardless of clinical and immunological criteria and should not be discontinued after childbirth irrespective of the level of counts of $\mathrm{CD} 4^{+} \mathrm{T}$ lymphocytes, since it is a leukocyte that activates and stimulates other leukocytes to multiply and attack antigens at the time of the onset of the treatment ${ }^{(9)}$.

The maternity of the study is currently updating its protocols for the prophylaxis of vertical transmission of HIV in delivery and puerperium, which is why its conduct is not in accordance with the new protocol and therapeutic guidelines of the Ministry of Health, as mentioned above. According to the maternity protocol, the use of AZT as a prophylaxis remains for all pregnant women regardless of viral load, at delivery until cord clamping. In the puerperium, maternal antiretroviral therapy (ART) will be according to the $\mathrm{CD} 4^{+} \mathrm{T}$ count and the clinical and immunological signs. Thus, it differs from the one advocated by the new $\operatorname{protocol}^{(9)}$.

Regarding the accomplishment of prenatal care by the seropositive pregnant women of the study, it was observed that the most women performed it and in more than seven visits. Other studies with seropositive pregnant women revealed prenatal coverage above the national coverage limit (85.0\%), with rates of $97.7 \%$ and $92.7 \%$, respectively ${ }^{(10-11)}$. In an epidemiological study carried out in a state in the Northeast of Brazil, a growing increase was observed throughout the years of prenatal consultation with this people, which reveals an important fact, since this is one of the only moments in which the woman attends the health service, enabling the diagnosis of HIV and preventive measures for vertical transmission ${ }^{(1)}$.

There was a prevalence of deliveries by elective cesarean section in half of the studied population, and deliveries by emergency cesarean section reached the rate of $81.5 \%$ of cesareans. The data found differ from the average of previous research results, where the prevalence was $63.0 \%$ in the South region and $72.7 \%$ in another study in the Southeast region, respectively ${ }^{(6-12)}$. In the perinatal prophylaxis and at the time of delivery, there was a significant increase in prevalence, when compared with the same studies that had an average coverage of perinatal prophylaxis of $41.7 \%$ and $54.5 \%$, and prophylaxis at delivery was between $67.0 \%$ and $77.3 \%$, respectively ${ }^{(1-4)}$.

Regarding the results of the evolution of pregnancy, the outcomes were positive, only one stillborn and five miscarriages. Also, obstetric complications were uncommon in other studies, similar to the expected in the population of non-seropositive pregnant women, as evidenced by the a study published in which a neonatal death due to acute neonatal suffering was identified as a more serious complication, which can happen to any pregnant woman, even with those who are not seropositive for HIV ${ }^{(11)}$.

Regarding the variables related to the newborn, the result of the prevalence of prematurity did not present a significant difference when compared to other studies, as well as low birth weight ${ }^{(1,13-14)}$. Prematurity is an event influenced by several factors, and there is a consensus in the literature that infectious processes are one of the causes of preterm birth ${ }^{(11-12)}$.

In the study, there was a statistical association regarding the number of consultations and prematurity. A study conducted in Guarapuava, state of Paraná, showed that more than half of the mothers of preterm infants performed between four and six visits ${ }^{(15)}$.

Prematurity as a cause of infant mortality has been studied in different countries. A case-control study has resulted in countless causes that lead a baby to premature birth, especially those related to the female genital tract, placental changes, placenta previa, and premature detachment and excess amniotic fluid. Other factors include mother's age (higher incidence in younger mothers), maternal infections, primiparity, more frequent in the first child. However, in most cases, the cause is unknown ${ }^{(15)}$. 
Besides to the complications that HIV infection can bring, there are the psychosocial issues with the hospitalization of preterm newborns. A study aimed at describing the parents' perceptions about the hospitalization of preterm infants and the care provided by the nursing team, revealing that the issue of the suffering caused by hospitalization motivates different feelings related to prematurity, financial and social issues, as well as the distancing of homes and families. The parents reported surprise, fear, insecurity, and guilt for infection, hospitalization, and prematurity ${ }^{(16)}$.

However, it is also scarce the availability of studies that identify HIV as the main cause of prematurity, considering that many factors are considered as risk for this event to occur, consequently the individualization of factors that can actually contribute to the preterm can be established only indirectly. Thus, it is verified that the prenatal follow-up is essential, thus the possible risk factors are detected and the complications avoided.

\section{Conclusion}

With the analysis of the data found in the delivery and birth indicators of HIV-positive women, it is concluded that the vulnerability and the highest risk of becoming ill occur in young adults with low level of education and socioeconomic level. The coverage indicator of pregnant women needs to improve their indexes, since a little more than half of the women performed seven antenatal consultations, negatively impacting the evolution of pregnancy with a percentage of pregnancy prophylaxis below the desired level.

\section{Acknowledgments}

We thank the Conselho Nacional de Desenvolvimento Científico e Tecnológico and to the Ministério da Saúde through the National Residency Program in Obstetric Nursing.

\section{Collaborations}

Castro RCMB contributed to the design of the project of the article. Gomes SM contributed with the design of the project, data collection and article writing. Damasceno AKC contributed to the relevant critical review of intellectual content. Bastos CVG and Araújo LC contributed with data collection and article writing. Coelho TS contributed in the relevant critical review of the intellectual content and approval of the final version to be published.

\section{References}

1. Lima ACMACC, Costa CC, Teles LMR, Damasceno AKC, Oriá MOB. Epidemiologic assessment of prevention of vertical transmission of HIV. Acta Paul Enferm. 2014; 27(4):311-8. doi: http:// dx.doi.org/10.1590/1982-0194201400053

2. Organização Mundial de Saúde (OMS). VIH/sida [Internet]. 2018 [citado 2018 out. 18]. Disponível em:http://www.who.int/es/news-room/factsheets/detail/hiv-aids

3. Ministério da Saúde (BR). Boletim Epidemiológico Aids e DST/Departamento de DST, Aids e Hepatites Virais [Internet]. 2017 [citado 2018 ago. 13]. Disponível em: http://www.aids.gov.br/pt-br/ taxonomy/term/595

4. Colasanti J, Rugama ML, Lifschitz K, Largaespada M, Flores-Lopéz B, Dodd C, et al. HIV testing rates among pregnant women in Managua, Nicaragua, 2010-2011. Rev Panam Salud Publica [Internet]. 2013 [cited 2018 Aug 13];33(1):15-21. Available from: https://www.scielosp.org/pdf/rpsp/2013. v33n1/15-21/en

5. Carvalho CFS, Silva RAR. Perfil sociodemográfico e de saúde de mulheres soropositivas em um pré-natal de alto risco. Cogitare Enferm. 2014; 19(2):292-8. doi: dx.doi.org/10.5380/ ce.v19i2.36981

6. Galvão MTG, Lima ICV, Cunha GH, Santos VF, Mindêllo MIA. Estratégia de mães com filhos portadores de HIV para conviverem com a doença. Cogitare Enferm. 2013; 18(2):230-7.doi: http:// dx.doi.org/10.5380/ce.v18i2.27630 
7. Menezes LSH, Palacios VRCM, Peixoto CAS, Alcântara MSV. Perfil epidemiológico de grávidas HIV positivas atendidas em maternidade pública de referência. Rev Para Med [Internet]. 2013 [citado 2018 ago. 13];27(2):1-9. Disponível em: http://files.bvs.br/upload/S/0101-5907/2013/ v27n2/a3676.pdf

8. Polgliane RBS, Leal, MC, Amorim MHC, Zandonade E, Santos Neto ET. Adequação do processo de assistência pré-natal segundo critérios do Programa de Humanização do Pré-natal e Nascimento e da Organização Mundial de Saúde. Ciênc Saúde Coletiva. 2014; 19(7):1999-2010. doi: http://dx.doi. org/10.1590/1413-81232014197.08622013

9. Ministério da Saúde (BR). Protocolo Clínico e Diretrizes Terapêuticas para Prevenção da Transmissão Vertical de HIV, Sífilis e Hepatites Virais [Internet]. 2017 [citado 2018 mar 10]. Disponível em:http://www.aids.gov.br/pt-br/pub/2015/ protocolo-clinico-e-diretrizes-terapeuticas-para-prevencao-da-transmissao-vertical-de-hiv

10. Guanabara MAO, Araújo MAL, Barros VL, Gondim APS, Pinheiro PMR, Oliveira FA. Gestantes com HIV/Aids acompanhadas em serviços públicos. Rev Enferm UFPI [Internet]. 2014 [citado 2018 mar 10]. 3(2):25-32. Disponível em: http:// www.ojs.ufpi.br/index.php/reufpi/article/ viewFile/1838/pdf

11. Holanda ER, Galvão MTG, Pedrosa NL, Paiva SS, Almeida RLF. Spatial analysis of infection by the human immunodeficiency virus among pregnant women. Rev Latino-Am Enfermagem. 2015; 23(3):441-9. doi: http://dx.doi. org/10.1590/0104-1169.0481.2574
12. Maia MMM, Lage EM, Moreira BCB, Deus EAB, Faria JG, Pinto JA, et al. Prevalência de infecções congênitas e perinatais em gestantes HIV positivas da região metropolitana de Belo Horizonte. Rev Bras Ginecol Obstet. 2015; 37(9):421-7. doi: http://dx.doi.org/10.1590/ S0100-720320150005355

13. Ministério da Saúde (BR). Departamento de Ações Programáticas Estratégicas. Atenção à saúde do recém-nascido: guia para os profissionais de saúde [Internet]. 2014 [citado 2018 mar 10]. Disponível em: http://bvsms.saude.gov.br/bvs/publicacoes/ atencao_saude_recem_nascido_v1.pdf

14. Nilson LG, Warmling D, Oliveira MSV, Gouveia GDA. Proporção de baixo peso ao nascer no Brasil e regiões brasileiras, segundo variáveis sócio-demográficas. Rev Saúde Pública. 2015; 8(1):69-82. doi: dx.doi.org/10.1590/S0102311X2013000200021

15. Moutinho A, Alexandra D. Parto pré-termo, tabagismo e outros fatores de risco: um estudo caso-controle. Rev Port Med Geral Fam [Internet]. 2013 [citado 2018 mar 10]; 29(2):107-12. Disponível em: http://www.scielo.mec.pt/pdf/ rpmgf/v29n2/v29n2a06.pdf

16. Pieszak GM, Paust AM, Gomes GC, Arrué AM, Neves ET, Machado LM. Hospitalization of premature infants: parents' perceptions and revelations about nursing care. Rev Rene. 2017; 18(5):591-7. doi: dx.doi.org/10.15253/21756783.2017000500005 